\title{
Biokuro savybių ir juo kūrenamų mažos bei vidutinès galios ịrenginių efektyvumo ir taršos parametrų tyrimai
}

Nerijus Pedišius,

Marius Praspaliauskas,

Mantas Valantinavičius,

Tomas Vonžodas,

Vladas Zaleskas,

Egidijus Lemanas,

Deimantė Čepauskienè

Lietuvos energetikos institutas, Siluminiu ìrengimu tyrimo

ir bandymu laboratorija,

Breslaujos g. 3, LT-44403 Kaunas

El.paštas Nerijus.Pedisius@lei.lt
Atlikti mažos galios šildymo katilų, kūrenamų biokuru, efektyvumo ir išmetamų emisijų tyrimai. Tyrimai vykdyti keliais etapais: pirmajame etape buvo eksperimentiškai tiriamos šiuo metu plačiausiai naudojamo biokuro, pagaminto iš biomasès, ir potencialiai perspektyvaus biokuro, pagaminto iš agromasès, savybès siekiant nustatyti, kaip toks kuras turi būti paruošiamas, kad efektyviai sudegtụ šildymo ịrenginiuose; antrajame etape atlikti oro / degiụjų produktų maišymosi ịvairios konstrukcijos šildymo katilų degimo kamerose ir oro / degimo produktų kanaluose skaitiniai, eksperimentiniai tyrimai siekiant užtikrinti tinkamą degimo produktų buvimo laiką karštojoje zonoje ir jų temperatūrą. Šiame darbe taip pat pateikiami kietujų dalelių (KD) koncentracijos pasiskirstymo degimo produktuose priklausomai nuo jų dydžio tyrimo rezultatai ir KD koncentracijos mažinimo metodų analizè.

Raktažodžiai: biokuro savybès, pelenų sudètis ir lydumas, vandens šildymo katilai, efektyvumas, emisijos, kietosios dalelès

\section{IVADAS}

Šiuo metu kietasis biokuras tapo itin populiarus, plačiai naudojamas mažos ir vidutinès galios šildymo îrenginiuose namų ūkio ir kitos paskirties objektuose. Nors biokuras daugiausia gaminamas iš medienos biomasès, nuo seno naudojamas namų ūkiuose šildymui ir maisto ruošai, tačiau per pastaruosius du dešimtmečius ịvyko pokyčių, nulemmusių šio kuro naudojimo spartų augimą šilumai gaminti vidutinès galios energetiniuose įrenginiuose. Tai susiję su globaliais siekiais mažinti iškastinio kuro naudojimą, o kartu anglies dvideginio $\left(\mathrm{CO}_{2}\right)$ ir kitų šiltnamio efektą sukeliančių dujų koncentracijas atmosferoje. Pagrindinis būdas, leidžiantis pasiekti šiuos tikslus, - at- sinaujinančių energijos išteklių naudojimo ir energiją tausojančių technologijų diegimo plètra.

Nuo 1996 iki $2014 \mathrm{~m}$. biokuro naudojimas šilumai ir elektrai gaminti išaugo dvigubai - nuo 505 iki 1085 k.t.n.e [1]. 2014 m. duomenimis, namų ūkiuose buvo naudojama apie $47 \%$ bendrojo medienos kuro kiekio, o centralizuoto šildymo katilinèse ir kogeneracinèse elektrinèse atitinkamai $41 \%$. Likę kiekiai šildymui ir technologiniams procesams vykdyti buvo sunaudoti pramonès, paslaugu ir žemès ūkio sektoriuose. Spartus biokuro poreikio augimas yra susijęs su vis intensyvesniu jo naudojimu ne tik naujai įrengtose šildymo sistemose, bet ir mažiau efektyviose senose šildymo sistemose, kurių taršos parametrai gerokai didesni. Lietuvoje apie 90 \% namų ūkių turi techniškai 
pasenusias šildymo sistemas, kurios, palyginti su naujosiomis sistemomis, daugiau teršia aplinką $\mathrm{CO}$, organiniais junginiais, kietosiomis dalelès ir policikliniais aromatiniais angliavandeniliais. Visi šie teršalai sukelia nemažą foninị gyvenamujų rajonų, apšildomų biokuru, užterštumą, ypač šildymo sezono metu, o užterštumas kietosiomis dalelèmis, kurių skersmuo $<10 \mu \mathrm{m}$, dažnai viršija leidžiamas koncentracijas.

Šioms problemoms spręsti buvo kreipiama nepakankamai dèmesio, nes formuota nuomonè, kad biokuro panaudojimas energijai gaminti teikia tik privalumus - leidžia mažinti $\mathrm{CO}_{2}$ taršą ir importuojamo iškastinio kuro naudojimą. Visiškai aišku, kad biokuro efektyvus panaudojimas mažos ir vidutinès galios įrenginiuose šilumos energijai gaminti reikalauja daugiau dèmesio skirti išsamiems ịvairių rūšių kietojo biokuro ir jo mišinių parametru, taip pat degimo proceso atskirų stadijų tyrimams, tiekiamo degimui oro maišymosi su degimo produktais procesų ir degimo kamerų konstrukcijoms optimizuoti, degimo produktų efektyviam valymui nuo kenksmingų dujinių degimo produktų ir kietųjų dalelių.

Sprendžiant šiuos uždavinius reikètų vadovautis Austrijos, Vokietijos, Švedijos, Suomijos ir Danijos geraja patirtimi. Šiose šalyse jau kelis dešimtmečius skiriama daug dèmesio biomasès terminio skaidymo sistemų technologinei pažangai, pasiekta svarbių rezultatų, ypač taršos mažinimo srityje. Pagrindinis šiose šalyse atliekamų mokslo tyrimų tikslas - sukurti mažos taršos, vadinamosios „nulinès taršos", biomasès terminio skaidymo sistemas panaudojant ivvairius technologinius sprendinius. Tobulinant šias technologijas daugiausia dèmesio sutelkiama i $[2-5]$ :

- naujų biokuro rūšių ir mišinių tyrimus, tinkamą jų pritaikymą irenginiuose;

- biomasès deginimo technologijų tyrimus įvairios galios jègainèse;

- naujų inovatyvių sistemų, veikiančių kombinuotu ciklu, kūrimą ir tobulinimą;

- priemonių degimo produktams valdyti kūrimą ir tobulinimą;

- biomasès dujinimo ir pirolizès technologiju tyrimus;

- šiluminio skaidymo procesų ir įrenginių automatinio valdymo sistemų tobulinimą ir diegimą.

Būtina pabrèžti, kad, nors sparčiai plètojamos naujos biomasès panaudojimo energijai gaminti technologijos, tiesioginis biokuro deginimas dar ilgai išliks pagrindiniu būdu šilumai ir net elektros energijai gaminti mažos ir vidutinès galios įrenginiuose.

Nagrinëjant esamą tyrimų būklę ir praktinius rezultatus galima daryti išvadą, kad medienos kuro paruošimas ir deginimas jau nebesukelia sunkiai sprendžiamų problemų. Tokio kuro sudetis ir savybès pasižymi pastovumu, yra gana plačiai išnagrinètos. Deginant paruoštą medienos kurą (granules ir briketus) vandens šildymo katilų iki $300 \mathrm{~kW}$ galios naudingumo koeficientas priartejja prie $90 \%$, t. y. iki efektyvumo lygmens reglamentuojamo standartais ir teisiniais aktais $[6,7]$. Tačiau dar išlieka tiek įrenginių konstrukcinių elementų ir tinkamo oro tiekimo ì degimo zoną tobulinimo darbai siekiant kuo efektyviau visiškai sudeginti kurą ir lakiąsias medžiagas, tiek įdiegimas techninių ir teisinių priemonių kietụjų dalelių emisijoms $\mathfrak{i}$ aplinką mažinti [8-11].

Sudètingesnè situacija, kai vietoj medienos vis dažniau pasirenkamas biokuras, pagamintas iš agromasès, kurią sudaro trumpos rotacijos sumedèję ir žoliniai augalai, žemès ūkio derliaus nuėmimo ir perdirbimo atliekos (šiaudai, išvalos ir išspaudos) bei kai kurie nekondiciniai produktai (grūdai, sèklos). Šios agromasès naudojimo šilumai gaminti sudetingumą lemia daugybè veiksnių:

- agromasė pasižymi didesniu mineralinių medžiagų kiekiu, dèl kurio, kurui sudegus, lieka daug pelenu, jų sudètis kelia gausybę praktinių proble$\mathrm{mų} \mathrm{[12-14];}$

- dèl didesnio kiekio šarminių elementų agromasèje pasireiškia ankstyvesnis pelenų lydumas ir padidintas skystosios ir dujinès junginių fazių formavimasis, jų visuminis efektas - pelenų ant ardyno lydymasis / sukepimas, nuosèdų ant karštų kūryklos ir dūmų dujų trakto šaltesnių paviršių susidarymas $[15,16]$. Šiuos reiškinius dažnai apibūdinama vienu terminu - šlakavimasis, bet iš tikrųjų tai skirtingi procesai, kurių priežastis glūdi agromasès cheminių junginių sudètyje. Šlakavimuisi daugiausia ịtakos turi Ca, $\mathrm{K}, \mathrm{Si}, \mathrm{Mg}, \mathrm{Na}, \mathrm{Al}$ junginiai. Vieni jų, kaip $\mathrm{K}, \mathrm{Na}$ ir Mg junginiai, mažina pelenų lydumo temperatūras, o Si, Al, Ca - didina. Silicio oksidas kartu su kalio ir natrio oksidais yra pagrindiniai aglomeracijos ir katilo „užsiteršimo“ sukèlèjai. 
Pelenų formavimosi ir jų šlakavimosi mechanizmams pastaraisiais metais skiriamas padidintas dèmesys [17-23], nes išsamūs duomenys apie šiuos procesus gali gerokai palengvinti agromasès panaudojimą termokonversijos procesuose;

- šlakavimosi reiškinio pasekmè - padidejęs pasipriešinimas šilumos pernašai, įrangos paviršių erozija ir korozija [15].

Pastarosios dvi problemos yra svarbiausios ir labiausiai riboja platų agromasès panaudojimą įrenginiuose, gaminančiuose šilumą. Būtina atkreipti dèmesi $\mathfrak{i}$ dar vieną svarbų veiksni - agromasès sudèties priklausomumą nuo jos rūšies, vegetacijos, dirbtinio tręšimo, derliaus nuemimo, sandèliavimo ir apdorojimo sąlygų [24]. Todèl tos pačios rūšies agromasès sudètis gali labai skirtis atsižvelgiant $\mathfrak{i}$ nurodytus veiksnius, pareikalauti lankstesnio degimo proceso valdymo ir reguliavimo.

Šiame straipsnyje pateikiami tyrimų komplekso rezultatai, siekiant spręsti šiuos uždavinius:

- ištirti vietinès potencialios agromasès ir jos pelenų sudèti, savybes, palyginti jas su medienos kuru;

- nustatyti mažos galios įrenginių, gaminamų Lietuvoje ir kūrenamų medienos kuru, efektyvumą ir emisijas ị aplinką;

- išplètoti KD emisijų iš mažos ir vidutinès galios ịrenginių mažinimo tyrimus, jų atskyrimo metodus, îvertinti jų savybes ir priklausomumą nuo kuro rūšies.

Tyrimų orientavimas ị šių uždavinių sprendimą Lietuvos energetikos instituto Šiluminių įrengimų tyrimo ir bandymų laboratorijoje buvo pradètas atsižvelgus ị bendrąsias biokuro išteklių panaudojimo tendencijas energijai gaminti. Svarbų impulsą šiems darbams plètoti suteikè Lietuvos Respublikos Vyriausybès $2001 \mathrm{~m}$. inicijuota „Atitikties ịvertinimo infrastruktūros (bandymo laboratorijų, sertifikacijos ịstaigų) plètros programa" [25], kurią vykdant sukurta ir sukomplektuota îranga mažos ir vidutinès galios šiluminių įrenginių, gaminamų Lietuvos gamintojų, tyrimams, bandymams ir atitikties vertinimams atlikti. Ši laboratorijos veikla toliau akredituota ir notifikuota, jos rezultatai pelnè tarptautini pripažinimą ir suteike gamintojams galimybę tiekti konkurencingus gaminius ị rinką.

Kito etapo, orientuoto daugiau i mokslinius kietojo kuro, ịskaitant ịvairų biokurą, panaudojimo tyrimus, pradžia reikia laikyti slènio SAN-
TAKA ịsteigimą / suformavimą (2010-2013 m.). Iš esmès buvo atnaujinta esama iranga, papildyta šiuolaikiška aparatūra ịvairių rūšių kietojo kuro ir jo degimo produktų - dujinių junginiu ir kietųjų dalelių, pelenų sudèčiai ir savybèms, degimo proceso efektyvumui ir su biokuru susijusiems kenksmingiems poveikiams deginimo irenginiams ir aplinkai tirti.

\section{KIETAJAM BIOKURUI GAMINTI NAUDOJAMOS BIOMASĖS SAVYBĖS}

Tyrimams pasirinkta ịvairių rūšių biomasè buvo suskirstyta $\mathfrak{i}$ tris grupes (1 lentelè): pirmoji - žemès ūkio derliaus nuemimo atliekos (rugių, kviečių, kvietrugių ir rapsų šiaudai); antroji - žoliniai augalai (šunažole, nendrinis dryžutis, kanape ir drambliažolè); trečioji - medienos (eglès, alksnio, beržo ir uosio) biomasè.

Biomasès parametrai tirti metodais, parengtais Tarptautinès standartizacijos organizacijos (ISO) ir priimtais Lietuvos standartizacijos departamento kietojo biokuro bandymų standartais: drègmès kiekis - pagal LST EN ISO 18134-1:2016; pelenų kiekis - pagal LST EN ISO 18122:2016 naudojant mufelinę laboratorinę krosni Nabertherm LVT/9/11/P330; šilumingumas - pagal LST EN 14918:2010 kalorimetru IKA C 5000; pagrindinių cheminių elementu (CHNS) kiekiai - pagal LST EN ISO 16948:2015 analizatoriumi Flash 2000; chloro koncentracija - jonų chromatografu Dionex ISC 5000 pagal LST EN ISO 16994:2015; mėginiu elementine sudètis - indukuotos plazmos optinès emisijos spektrometru (ICP-OES).

Kaip matyti iš 1 lentelèje pateiktų duomenų, elementineje tirtosios biomasès ir biokuro sudètyje vyrauja trys pagrindiniai elementai: anglis $(\mathrm{C})$, vandenilis $(\mathrm{H})$ ir deguonis $(\mathrm{O})$. Kartu šie elementai sudaro apie 94-99\% sausosios masès. Atskirų biomasès rūšių šilumingumas gerai koreliuoja su anglies biomaseje kiekiu. Medienos šilumingumo vidurkis siekia beveik $19 \mathrm{MJ} / \mathrm{kg}$, o jos peleningumas - $0,7 \%$. Šiaudų ir žolių šilumingumas yra kiek mažesnis, atitinkamai 16,5 ir $17,7 \mathrm{MJ} / \mathrm{kg}$ ), bet jų peleningumas siekia $~ 5 \%$.

Nagrinejant agromasès panaudojimą energijai gaminti ir su tuo kylančius sunkumus, svarbu atkreipti dèmesị $\mathfrak{x}$ junginius, kurių sudètyje yra azoto $(\mathrm{N})$, chloro $(\mathrm{Cl})$ ir sieros $(\mathrm{S})$. Nors jų nèra 
1 lentelè. Žemès ūkio atliekų, žolinių augalų ir medienos elementinè sudètis, šilumingumas ir peleningumas

\begin{tabular}{|c|c|c|c|c|c|c|c|c|}
\hline \multirow[t]{2}{*}{ Biomasès rūšis } & $\begin{array}{c}\text { Šilumingumas } \\
\text { (s.k.a.) }\end{array}$ & $\begin{array}{l}\text { Peleny } \\
\text { kiekis }\end{array}$ & C & H & N & $\mathbf{S}$ & 0 & Cl \\
\hline & $\mathrm{MJ} / \mathbf{k g}$ & \multicolumn{7}{|c|}{$\%$} \\
\hline \multicolumn{9}{|c|}{ Žemès ūkio atliekos } \\
\hline Rugių šiaudai & 16,63 & 4,3 & 45,48 & 6,01 & 0,63 & 0,05 & 43,51 & 0,09 \\
\hline Kviečių šiaudai & 16,91 & 3,9 & 42,68 & 5,41 & 0,99 & 0,13 & 46,90 & 0,09 \\
\hline Kvietrugių šiaudai & 16,56 & 3,9 & 45,21 & 6,17 & 0,63 & 0,05 & 44,04 & 0,11 \\
\hline Rapsų šiaudai & 15,78 & 5,8 & 43,23 & 5,97 & 1,08 & 0,23 & 42,51 & 0,29 \\
\hline Vidurkis & 16,47 & 4,5 & 44,15 & 5,89 & 0,83 & 0,12 & 44,24 & 0,15 \\
\hline \multicolumn{9}{|c|}{ Žoliniai augalai } \\
\hline Šunažolè & 17,67 & 7,65 & 45,44 & 5,54 & 1,39 & 0,21 & 39,77 & 0,04 \\
\hline Nendrinis dryžutis & 17,66 & 5,73 & 46,09 & 5,75 & 1,37 & 0,15 & 41,06 & 0,05 \\
\hline Kanapès & 17,78 & 3,51 & 47,37 & 5,47 & 0,37 & 0,02 & 43,25 & - \\
\hline Drambliažolè & 17,69 & 4,85 & 46,82 & 5,83 & 0,84 & 0,08 & 42,34 & 0,05 \\
\hline Vidurkis & 17,7 & 5,44 & 46,43 & 5,65 & 0,99 & 0,12 & 41,61 & 0,05 \\
\hline \multicolumn{9}{|c|}{ Mediena } \\
\hline Eglè & 19,1 & 0,9 & 50,64 & 5,78 & 0,21 & 0 & 42,68 & 0,05 \\
\hline Alksnis & 18,92 & 0,84 & 49,08 & 5,94 & 0,34 & 0 & 43,2 & 0,02 \\
\hline Beržas & 18,77 & 0,65 & 49,79 & 6,14 & 0,23 & 0 & 43,19 & 0,01 \\
\hline Uosis & 18,67 & 0,5 & 49,95 & 5,76 & 0,24 & 0 & 43,55 & 0,02 \\
\hline Vidurkis & 18,87 & 0,72 & 49,87 & 5,91 & 0,26 & 0 & 43,16 & 0,03 \\
\hline
\end{tabular}

daug, bet jie iš esmès keičia pelenų sudetti ir formavimąsi ant ardyno, nuosèdų susidarymą ant karštų kūryklos paviršių ir šaltesnių dūmų trakto paviršių, sudaro dalį emisijų i t aplinką. Azoto (N) kiekio vidurkis medienos biomaseje sudaro $0,26 \%$, tačiau agromaseje azoto kiekiai siekia $1 \%$. Degimo metu kure esantis azotas kartu su ore esančiu azotu dalyvauja cheminèse reakcijose, kurių galutinis produktas, atsižvelgiant $\mathfrak{i}$ konkrečių reakcijų sąlygas, gali būti dujinis $\mathrm{N}_{2}$ ir azoto oksidai $\left(\mathrm{NO}_{\mathrm{x}},\left[\mathrm{NO}, \mathrm{NO}_{2}, \mathrm{~N}_{2} \mathrm{O}\right]\right)$, kurių galutinè koncentracija daugiausia priklauso nuo oro pertekliaus, temperatūros degimo zonoje, azoto koncentracijos kure ir pakuros konstrukcijos.

$\mathrm{S}$ ir $\mathrm{Cl}$ kiekiai didžiausi javų šiauduose (iki 0,12-0,15\%), mažiau (iki 0,12-0,05 \%) žoliniuose augaluose ir jų beveik nèra medienoje. Šarminiai chloridai dalyvauja cheminèse reakcijose, kurių metu susidarę junginiai esant aukštai temperatūrai gali lydytis arba virsti garais ir formuoti žalingas nuosèdas ant paviršių.

Degimo proceso emisijoms ir įrangos medžiagoms dideli poveiki daro S, esanti kure. Sieros junginiai degimo produktuose gali būti aerozolių ar dujų pavidalu, pavyzdžiui, $\mathrm{SO}_{2}$ (nedideliais kiekiais, kaip $\mathrm{SO}_{3}$ ), ir sukelti žemos temperatūros koroziją šilumokaičiuose ir dūmtakiuose.

Kita svarbi biomasès sudedamoji dalis - metalų junginiai, kurių vieni patenka $\mathfrak{i}$ augalų sudetț vegetacijos metu iš dirvožemio arba trąšų ir dalyvauja biologinèje medžiagų apykaitos sistemoje, kiti patenka í agromasę kaip pašalinis produktas nuimant derlių, ji apdorojant, transportuojant ar sandèliuojant.

2 lentelëje pateikti svarbiausių metalų, lemiančių pelenų kiekị ir jų savybes, koncentracijos atskirose biomasès rūšyse. Iš karto matyti, kad visais atvejais daugiausia yra $\mathrm{Ca}, \mathrm{Si}, \mathrm{K}, \mathrm{Mg}, \mathrm{Na}$ ir $\mathrm{Fe}$, bet jų vieta sekoje, kaip ir kitų mažiau esančių elementų, kinta. Šis kitimas gali būti daugelio veiksnių pasekmė ir reikalauja išsamesnių tyrimų. Tačiau svarbiausių elementų padètis sekose yra tokia:

- medienoje - Ca, K, Si ir Mg, o Na, Zn ir Fe kiekiai beveik vienodi ir gerokai mažesni. Kitų elementų kocentracijos yra mažesnès nei $10 \mathrm{mg} / \mathrm{kg}$; - javų šiauduose - Si, K, Ca ir Mg, toliau eina $\mathrm{Na}, \mathrm{Fe}, \mathrm{Pb}$ ir kiti elementai; 
2 lentelè. Metalų kiekiai žemès ūkio atliekose, žoliniuose augaluose ir medienoje

\begin{tabular}{|c|c|c|c|c|c|c|c|c|c|c|c|c|c|c|}
\hline $\begin{array}{c}\text { Elementų } \\
\text { kiekiai } \\
(\mathrm{mg} / \mathrm{kg})\end{array}$ & $\mathrm{Ca}$ & $\mathrm{Si}$ & $\mathrm{Fe}$ & K & $\mathrm{Mg}$ & $\mathrm{Na}$ & Ti & $\mathrm{Ba}$ & Cd & $\mathrm{Cr}$ & $\mathrm{Mn}$ & $\mathrm{Ni}$ & $\mathrm{Pb}$ & Zn \\
\hline $\begin{array}{l}\text { Rugių } \\
\text { šiaudai }\end{array}$ & 2239 & 15397 & 156 & 690 & 823 & 55 & 120 & - & - & 13,1 & 20,5 & 1,5 & 120 & 7,0 \\
\hline $\begin{array}{l}\text { Kviečių } \\
\text { šiaudai }\end{array}$ & 1689 & 11466 & 94 & 6427 & 687 & 81 & 185 & 31 & 0,4 & 8,2 & 27,1 & 0,3 & 56 & 7,5 \\
\hline $\begin{array}{c}\text { Kvietrugių } \\
\text { šiaudai }\end{array}$ & 2468 & 7235 & 141 & 8077 & 587 & 160 & 17 & - & - & 7,6 & 25,4 & 2,5 & 74,7 & 4,9 \\
\hline $\begin{array}{l}\text { Rapsų } \\
\text { šiaudai }\end{array}$ & 11173 & 7183 & 143 & 12385 & 1538 & 372 & 23 & - & - & 17,7 & 21,8 & 0,3 & 128,7 & 7,4 \\
\hline Vidurkis & 4392 & 10320 & 133 & 6894 & 908 & 167 & 86 & 31 & 0,4 & 11,7 & 23,7 & 1,2 & 94,8 & 6,7 \\
\hline $\begin{array}{l}\text { Nendrinis } \\
\text { dryžutis }\end{array}$ & 3511 & 1850 & 245 & 2700 & 851 & 200 & 15 & 7,5 & 0,06 & 3,5 & - & - & 2,1 & 18,2 \\
\hline Kanapès & 6715 & 2845 & 340 & 1324 & 420 & 64 & 25 & 4,7 & 0,07 & 3,9 & 27 & 2,3 & 3,8 & 21 \\
\hline $\begin{array}{c}\text { Dramblia- } \\
\text { žolé }\end{array}$ & 2897 & 10800 & 47,6 & 4990 & 752 & 111 & 2,4 & 12,5 & 0,5 & 2,6 & 73,6 & 2,9 & 4,5 & 14,4 \\
\hline Vidurkis & 4374 & 5165 & 211 & 3005 & 674 & 125 & 14,1 & 8,2 & 0,2 & 3,3 & 50,3 & 2,6 & 3,5 & 17,9 \\
\hline Eglè & 924 & 256 & 44 & 352 & 124 & 21 & 3,0 & - & - & 0 & 5,4 & 0,9 & 1,8 & 7 \\
\hline Alksnis & 2018 & 546 & 17,9 & 490 & 145 & 6,4 & 0,8 & 5,2 & 0,22 & 0 & 10,6 & 0,7 & 3,1 & 6,9 \\
\hline Beržas & 1739 & 607 & 6,8 & 985 & 182 & 5,4 & 0,9 & 4,7 & 0,3 & 0 & 7,1 & 0,9 & 1,9 & 74,5 \\
\hline Uosis & 3697 & 475 & 22,4 & 1647 & 246 & 75 & 1,2 & 11,2 & 0,5 & 0 & 6,4 & 2,4 & 7,4 & 5,3 \\
\hline Vidurkis & 2094 & 471 & 22,8 & 868 & 174 & 26,9 & 1,5 & 7,1 & 0,3 & 0 & 7,4 & 1,2 & 4,1 & 23,4 \\
\hline
\end{tabular}

- žoliniuose augaluose - (panašiai kaip šiauduose) Si, Ca, K, Mg ir Fe, Na, Mn ir kiti elementai.

Taigi tirtụjų rūšių biomasèje daugiausia tų pačių elementų $\mathrm{Ca}, \mathrm{K}, \mathrm{Si}$ ir Mg bei kiek mažiau Na ir $\mathrm{Fe}$. Jei medienoje daugiausia yra $\mathrm{Ca}$, tai agromasèje - Si. Suminès vidutinès metalų koncentracijos šiauduose ir žoliniuose augaluose yra apytikriai 6 ir 4 kartus didesnès nei medienoje. Kaip parodyta 3 lentelëje, tai koreliuoja su pelenų kiekių santykiais ir pelenų sudètimi.

\section{KURO, GAMINAMO IŠ MEDIENOS IR AGROMASĖS, PELENŲ SAVYBĖS}

Pelenų lydumas tirtas pagal LST CEN/TS 15370-1 naudojant aukštatemperatūrinę krosnį su videokamera. Pagal méginio formos pokyčius didejjant temperatūrai buvo nustatomos šios būdingosios lydumo temperatūros: SST - susitraukimo; DT - deformacijos; HT - pusrutulio formos ir FT - išsiliejimo.

3 lentelè. Tirtujų medienos ir agromasės rūšių bei jų pelenழ̨ elementinių sudęčių palyginimas

\begin{tabular}{|c|c|c|c|c|c|c|c|}
\hline $\begin{array}{l}\text { Medienoje ir } \\
\text { agromasėje / pelenuose, \% }\end{array}$ & $\mathrm{Ca}$ & K & $\mathrm{Si}$ & $\mathbf{P}$ & Mg & Al & $\mathrm{Na}$ \\
\hline Beržas & $0,14 / 31,2$ & $0,05 / 12,7$ & $0,03 / 0,9$ & $0,25 / 1,6$ & $0,02 / 3,4$ & $-/ 0,2$ & $0,22 / 0,5$ \\
\hline Eglè & $0,14 / 29,4$ & $0,04 / 12,8$ & $0,03 / 1,6$ & $0,24 / 1,4$ & $0,01 / 2,4$ & $-/ 0,3$ & $0,21 / 0,6$ \\
\hline Nendrinis dryžutis & $0,24 / 4,8$ & $1,89 / 45,7$ & $0,25 / 7,9$ & $0,43 / 2,8$ & $0,10 / 1,9$ & $0,01 / 0,2$ & $0,25 / 0,5$ \\
\hline Kanapè & $0,70 / 22,2$ & $0,17 / 18,3$ & $0,31 / 0,2$ & $0,31 / 0,3$ & $0,08 / 2,6$ & $0,05 / \mathbf{0 , 0 1}$ & $0,24 / 0,2$ \\
\hline Grikių šiaudai & $0,99 / 19,2$ & $1,93 / 41,9$ & $\mathrm{n} / \mathrm{d} / \mathbf{n} / \mathbf{d}$ & $0,41 / 2,7$ & $0,08 / 1,4$ & $0,01 / 0,2$ & $0,24 / 0,6$ \\
\hline Kviečių šiaudai & $0,26 / 6,0$ & $1,27 / 35,9$ & $0,85 / 18,1$ & $0,35 / 2,2$ & $0,09 / 1,9$ & $0,02 / 0,4$ & $0,24 / 0,5$ \\
\hline Rapsų šiaudai & $1,15 / 19,8$ & $2,08 / 37,4$ & $0,27 / 4,6$ & $0,36 / 1,6$ & $0,14 / 2,1$ & $0,03 / 0,5$ & $0,30 / \mathbf{0 , 8}$ \\
\hline Rugių šiaudai & $0,34 / 6,5$ & $0,98 / 24,2$ & $0,90 / 20,8$ & $0,36 / 1,7$ & $0,10 / 2,0$ & $0,04 / 0,8$ & $0,27 / 0,5$ \\
\hline
\end{tabular}


Iš 1 pav. pateiktų kiekvienos tirtosios biomasès rūšies būdingụjų temperatūrų matyti, kad SST reikšmè, rodanti méginio tūrio pokyčių pradžią, daugeliui rūšių kinta nuo 700 iki $850^{\circ} \mathrm{C}$. Šiuo požiūriu netgi medienos SST tik vidutiniškai $\leq 100{ }^{\circ} \mathrm{C}$ yra didesnè nei šiaudų SST ir tik žolinių augalų, kanapių ir šunažolių, SST artejja iki $1100^{\circ} \mathrm{C}$. Labai aiškiai matoma, kad medienos DT, HT ir FT reikšmès yra beveik vienodos ir artimos $1500{ }^{\circ} \mathrm{C}$. Pagal šiuos parametrus tik kanapè artima medienai, o kitų rūšių DT reikšmè išlieka $850-950^{\circ} \mathrm{C}$. Tai reiškia, kad deginant tokią agromasę prasideda procesai, sukeliantys ankstyvą pelenų lydymąsi ir junginių fazinius virsmus.

Siekiant nustatyti, kokie elementai daugiausia veikia pelenų lydumą, buvo atliekama rūšių me- dienos biomasès, agromasès ir jų pelenų elementinè analizè, rezultatai pateikti 3 lentelèje.

Kaip matyti iš 3 lentelèje pateiktų rezultatų, visų agromasès mèginių pelenuose nustatytos didesnès $\mathrm{K}$, Si elementuc koncentracijos nei medienos mèginių pelenuose. Iš agromasès grupès pagal $\mathrm{Ca}$, $\mathrm{K}$ ir kitų elementų kiekị išsiskiria kanapès, kurių elementiné sudètis labai artima medienos pelenų sudéčiai. Medienos pelenuose vyrauja $\mathrm{Ca}, \mathrm{K}$ ir $\mathrm{Mg}$, Si ir P kiekiai mažesni nei 1,5\%. Šiaudų pelenuose daugiausia yra K, Ca ir Si, kitų elementų 0,5-2,5\%.

Siekiant ịvertinti, ar elementinè sudètis lemia pelenų lydymosi temperatūrą, atlikta determinacijos koeficiento $\mathrm{R}^{2}$, tiesinio priklausomumo tarp kiekvieno elemento kiekio ir atskiros lydumo stadijos būdingosios temperatūros atveju, analizé, rezultatai pateikti 4 lentelèje.

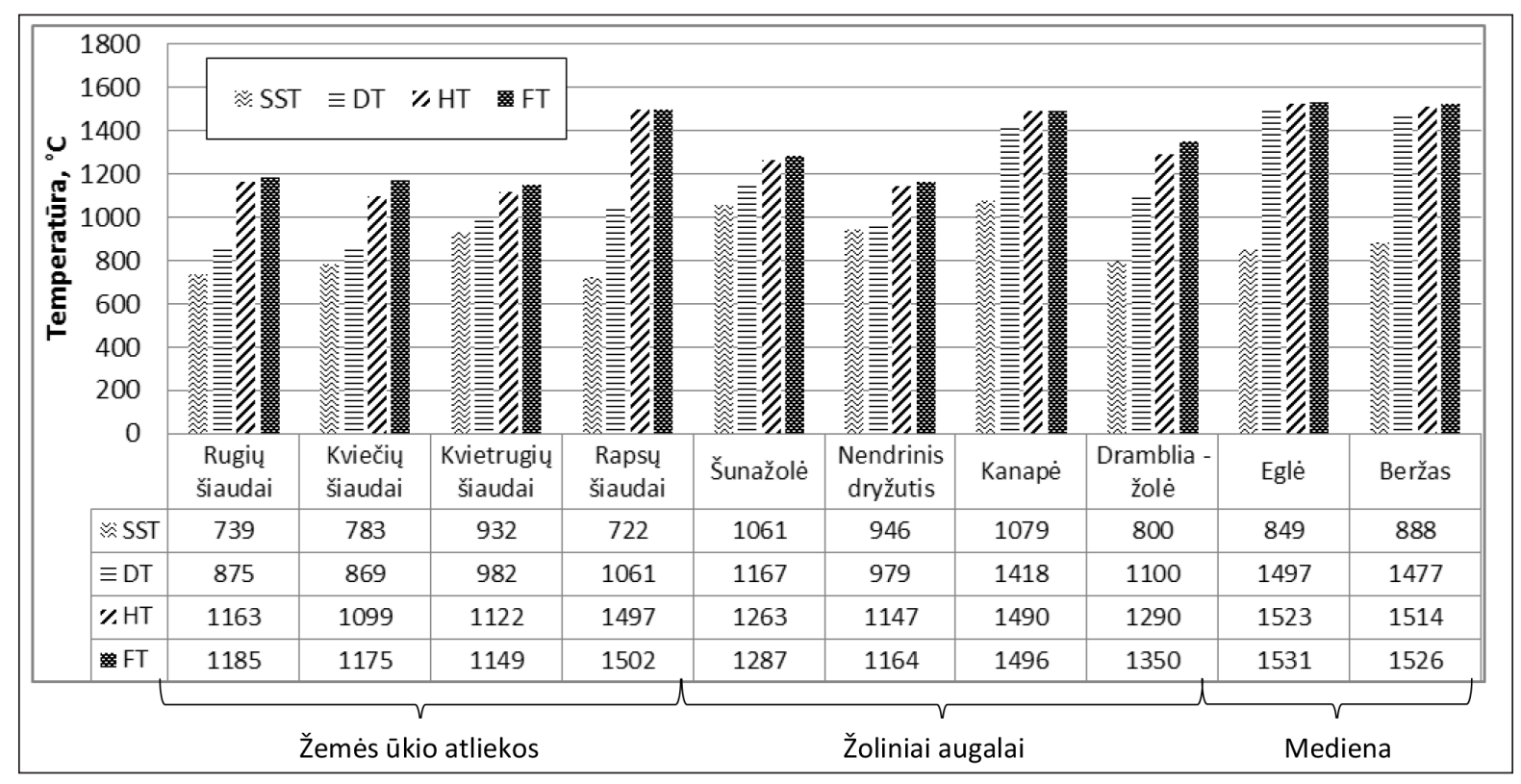

1 pav. Būdingosios pelenų lydumo temperatūrų reikšmès

4 lentelè. Pelenų lydymosi temperatūros ir atskirų elementų koncentracijos koreliacija

\begin{tabular}{|c|c|c|c|c|}
\hline & SST & DT & HT & $\mathbf{F T}$ \\
\hline $\mathrm{Si}$ & $-0,41\left(R^{2}=\mathbf{0 , 1 7}\right)$ & $-0,86(\mathbf{0 , 7 4 )}$ & $-0,79(\mathbf{0 , 6 2})$ & $-0,78(\mathbf{0}, \mathbf{6 0})$ \\
\hline$P$ & $-0,37(\mathbf{0 , 1 4 )}$ & $-0,02(\mathbf{0 , 0 0})$ & $-0,25(\mathbf{0 , 0 6 )}$ & $-0,24(\mathbf{0}, \mathbf{0 6})$ \\
\hline $\mathrm{Ca}$ & $-0,24(\mathbf{0 , 0 6 )}$ & $0,36(\mathbf{0 , 1 3 )}$ & $0,65(\mathbf{0 , 4 3 )}$ & $0,66(\mathbf{0 , 4 4 )}$ \\
\hline $\mathrm{Na}$ & $-0,68(0,46)$ & $-0,06(\mathbf{0 , 0 0 )}$ & $-0,01(\mathbf{0 , 0 0 )}$ & $-0,01(\mathbf{0 , 0 0 )}$ \\
\hline $\mathrm{Mg}$ & $-0,45(\mathbf{0 , 2 0 )}$ & $0,21(\mathbf{0 , 0 4 )}$ & $-0,06(\mathbf{0 , 0 0 )}$ & $-0,05(\mathbf{0}, \mathbf{0 0})$ \\
\hline $\mathrm{K}$ & $-0,63(0,39)$ & $-0,67(\mathbf{0 , 4 5 )}$ & $-0,44(\mathbf{0 , 1 9 )}$ & $-0,44(\mathbf{0 , 2 0})$ \\
\hline Al & $-0,50(\mathbf{0 , 2 5 )}$ & $-0,42(\mathbf{0 , 1 8})$ & $-0,35(\mathbf{0 , 1 2 )}$ & $-0,36(\mathbf{0}, \mathbf{1 3})$ \\
\hline
\end{tabular}


Iš gautų rezultatų matyti, kad tik keliais atvejais pasireiškia pakankamo lygio koreliacija, leidžianti daryti išvadas apie būdingosios lydumo temperatūros priklausomumą nuo atskiro elemento kiekio. Didžiausią poveiki DT, HT ir FT temperatūroms daro $\mathrm{Si}$, kurio kiekiui didèjant temperatūros mažèja. Ca kiekio didejimas sukelia HT ir FT didèjimą, t. y. jo poveikis stipriau pasireiškia galutinèse lydumo stadijose. Na ir K poveikis, atvirkščiai, stipriau pasireiškia pradinèse lydumo stadijose, ir jų kiekio didejjimas mažina ST reikšmes. Analogiškas K poveikis taip pat stebimas ir DT reikšmèms. Apie $\mathrm{Al}$ ir kitų elementų poveikị daryti išvadų negalima, nes determinacijos koeficiento reikšmès $\leq 0,25$. Galima daryti prielaidą, kad pavienis elementas tiesiogiai nepaveikia lydumo fazių temperatūrų, reikalinga išsamesnè vienu metu pasireiškiančio kelių elementų poveikio analizè.

Apibendrinus analizès duomenis galima daryti prielaidą, kad didejant $\mathrm{Si}, \mathrm{K}$ ir Na kiekiui pelenų lydumo temperatūros mažèja, o esant didesniam Ca kiekiui jos dideja. Šie rezultatai koreliuoja su kitų autorių darbais [15, 24, 26]. Laikoma, kad vienas pagrindinių elementų, darančių daugiausia ittakos pelenų lydymuisi, yra K, kuris kartu su Si suformuoja silikatus, besilydančius esant žemai (apie $750{ }^{\circ} \mathrm{C}$ ) temperatūrai [24]. Degimo metu, esant dideliam $\mathrm{K}$ kiekiui, gali susidaryti ne tik $\mathrm{K}$ silikatai, bet ir kiti K junginiai (chloridai, sulfatai, karbonatai). Šių K junginių lydymosi temperatūra taip pat žema ir siekia $770{ }^{\circ} \mathrm{C}$ [26]. Na, kaip ir $\mathrm{K}$, mažina pelenų lydymosi temperatūrą. Pelenuose $\mathrm{K}$ ir Na transformacijos mechanizmai yra panašūs. Kadangi K sukeliami poveikiai yra ge- rokai didesni, o Na kiekiai labai maži, dažnai $\mathrm{Na}$ nèra atskirai išskiriamas, o tapatinamas su K [15].

\section{MAŽOS GALIOS İRENGINIŲ, KŪRENAMỤ BIOKURU, EFEKTYVUMO TYRIMAI}

Mažos galios (nuo 8 iki $50 \mathrm{~kW}$ ) naujai pagamintų Lietuvoje biokuru kūrenamų šildymo įrenginių efektyvumas ir emisijos, ypač kietųjų dalelių, buvo tiriamos eksperimentiniame laboratoriniame irenginyje. Irenginiu naudingumo koeficientui nustatyti taikytas tiesioginio balanso metodas. Ištirti vandens šildymo katilų, kūrenamų medienos granulèmis (21 vnt.), malkine mediena (16 vnt.), iš kurių devyni dujų generacinio tipo katilai ir septyni ịprastiniai katilai, septynių malkomis kūrenamų krosnelių efektyvumas [27] ir KD emisijos [28]. KD masès koncentracijos matuotos automatiniu izokinetiniu $\mathrm{KD}$ rinktuvu Isostac Basic $\mathrm{HV}$, įrenginiams veikiant vardine galia šiluminių įrenginių tyrimo ịrenginyje. KD pasiskirstymas pagal dydi buvo matuojamas spektrometru Promo 2000/3000, dūmų dujų sudètis - dujų analizatoriais. Taip pat tirti KD megginiai, paimti iš eksploatuojamų didesnès galios katilų.

\section{Šildymo įrenginių efektyvumas}

Ivertinant efektyvumo tyrimo rezultatus buvo atsižvelgiama ị standartų ir teisès aktų reikalavimus. Reikalavimai kietuoju kuru kūrenamų katilų efektyvumui, kuriuos pateikia standartas [6], nurodyti 5 lentelëje.

Naudingumo koeficiento tyrimo rezultatai apibendrinti 2 ir 3 pav. Kaip matyti iš 2 pav., daugumos

5 Ientelè. Naudingumo koeficiento reikalavimai pagal [6]

\begin{tabular}{|c|c|c|c|c|}
\hline Katilo klasè & Taikomas standartas & Katilo galia kW & Naudingumo koeficientas, \% & Naudingumo koeficiento formule \\
\hline \multirow{2}{*}{5} & \multirow{2}{*}{ LST EN 303-5: 2012} & 10 & 88 & \multirow{2}{*}{$\eta=87+\log Q_{n}$} \\
\hline & & 300 & 89 & \\
\hline \multirow{2}{*}{4} & \multirow{2}{*}{ LST EN 303-5: 2012} & 10 & 82 & \multirow{2}{*}{$\eta=80+2 \log Q_{n}$} \\
\hline & & 300 & 84 & \\
\hline \multirow{2}{*}{3} & \multirow{2}{*}{ LST EN 303-5: 2012} & 10 & 73 & \multirow{2}{*}{$\eta=67+6 \log Q_{n}$} \\
\hline & & 300 & 82 & \\
\hline \multirow{2}{*}{2} & \multirow{2}{*}{ LST EN 303-5: 2000} & 10 & 63 & \multirow{2}{*}{$\eta=57+6 \log Q_{n}$} \\
\hline & & 300 & 72 & \\
\hline 1 & LST EN 303-5: 2000 & $\frac{10}{300}$ & $\begin{array}{l}53 \\
62\end{array}$ & $\eta=47+6 \log Q_{n}$ \\
\hline
\end{tabular}

Pastaba. $Q_{n}-$ katilo vardinė galia $k W$. 


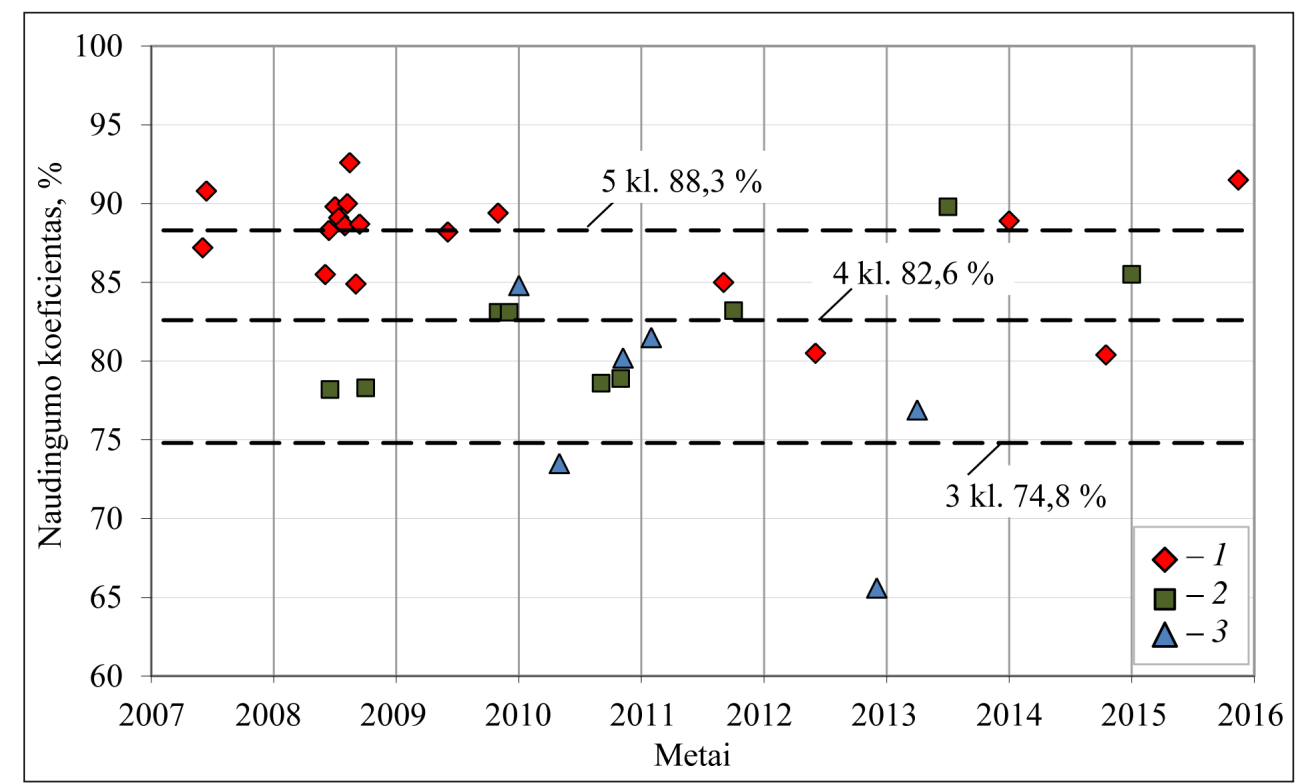

2 pav. Kietojo kuro katilų naudingumo koeficientų palyginimas su nustatytais reikalavimais 20 kW galios katilui (5 lentelè): 1 - medienos granulèmis kūrenamas katilas; 2 - malkomis kūrenamas dujų generacinis katilas; 3 - malkomis kūrenamas apatinio degimo katilas

granulèmis kūrenamų katilų naudingumo koeficiento reikšmių vidurkis visiškai priartèjo prie $90 \%$ ir tenkina 5 klasès reikalavimus. Šio tipo katilai yra gerokai pranašesni už kito tipo katilus, naudojančius mažiau paruoštą kurą, kurie periodiškai užkraunami ir neturi ittaisų degimo procesui valdyti. Todèl pastarųjų katilų naudingumo koeficientas siekia 4 klasès, o dažniausiai - tik 3 klasès reikalavimus.
Toks skirtumas atsiranda, nes specialiai paruoštas medienos granulių kuras pasižymi geresnèmis savybèmis, o dèl vienodais intervalais automatiškai tiekiamo kuro degimo procesas tampa lengvai ir efektyviai valdomas. Tai patvirtina židinių ir krosnelių tyrimo rezultatai, kurių efektyvumas pastebimai dideja gerinant paruoštą kurą ir oro degimui tiekimą (3 pav.). Ypač svarbią reikšmę turi tinkamas oro tiekimo valdymas kuro

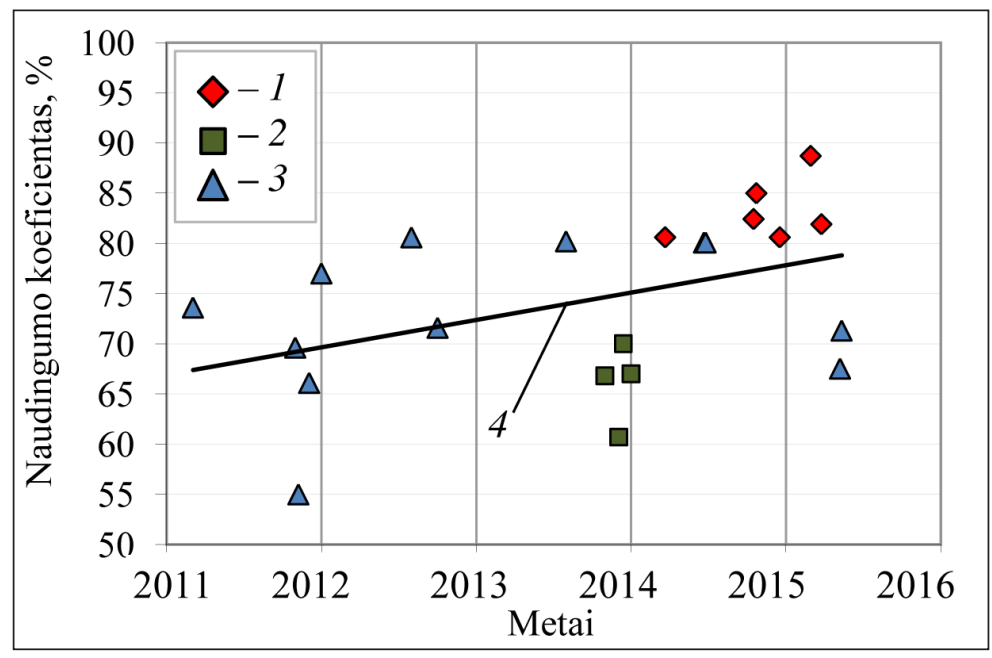

3 pav. Gaminamų židinių ir krosnelių naudingumo koeficiento kitimo tendencija: 1 - medienos granulèmis kūrenama krosnelè; 2 - malkomis kūrenamas židinių įdèklas; 3 - malkomis kūrenama krosnelè; 4 - tiesiškas priklausomumas taikant mažiausių kvadratų metodą 
įdiegimo metu, kai nevisiško degimo emisijos pasiekia didžiausias reikšmes.

Apskritai mažos galios kietojo biokuro katiluose vienu svarbiausių parametrų, lemiančių kuro visišką sudegimą, yra degimo produktų ir oro srautų, tiekiamų degimui, efektyvus maišymasis visose kuro degimo stadijose. Kadangi galutinis lakiujų dujinių produktų sudeginimas vyksta tiekiant antrinį orą, ịsisavintas ir pradètas praktiškai taikyti skaitinis maišymosi proceso modeliavimas ivvairios formos kamerose nustatomas pasitelkus ANSYS FLUENT v.14.0 kompiuterinès skysčiu dinamikos programą ir ịvairius turbulentiškumo modelius.

4 pav. pateiktas vienos iš skaitiniam modeliavimui pasirinktos degimo kameros su natūralia trauka supaprastintas dvimatis (2D) pavyzdys, siekiant nustatyti antrinio oro ittraukimo $\mathfrak{i}$ degimo kamerą tinkamiausią vietą ir įsiurbiamo oro kiekị. Modeliavimas atliktas keičiant antrinio oro tiekimo vietas.

Antrinio oro srovès, įtraukiamos per plyši užpakalinejje sienelëje, ir pagrindinio srauto sąveikos dinamiką atspindi 4a, b pav. pateikti skaičiavimo rezultatai. Matyti, kad tokiu atveju antrinio oro srovę galima tiekti taip, kad ji būtų tarp dviejų ganètinai stabilių sūkurių, kurių apatinị formuoja srauto atitrūkimas aptekant kanalo posūkio kampą ir ištekanti antrinio oro srove, kaip kliūtis pagrindiniam srautui (4b pav.). Tokiu būdu antrinis oras patenka ị pagrindinio srauto vidurị, užtikrina efektyvesni susimaišymą ir tolydų greičio pasiskirstymą kameros skerspjūvyje.
Per plyšị priekinėje sienelèje ( $4 c, d$ pav.) antrinio tiekimas smarkiai padidina greičio pasiskirstymo netolygumą kameros skerspjūvyje nepriklausomai nuo ittekejjimo vietos. Nors šiuo atveju antriniam orui ittekèti sąlygos yra palankesnès, bet itin padidejja greičio pasiskirstymo kameroje netolygumas ir srautų maišymasis.

Šie skaičiavimai buvo išplètoti $\mathfrak{i}$ cilindrinès formos kameras taikant maišymosi efektyvumui vertinti matematini metodą, pagrịstą išsisluoksniavimo intensyvumo skaičiavimu [29]. Šių metodų taikymas leis išspręsti daug svarbių uždavinių, susietų su degimo kamerų konstrukcijų parinkimu, antrinio oro tiekimu ir efektyviu srautų susimaišymu.

\section{Šildymo įrenginių KD emisijų koncentracijos ir pasiskirstymas pagal dydi}

5 pav. pateikti anksčiau nurodytų įrenginių KD emisijų tyrimo rezultatai, juc palyginimas su reglamentuojamais reikalavimais [6], kurie pažymèti punktyrinemis linijomis, nurodančiomis $\mathrm{KD}$ ribas $75-60$ ir $60-40 \mathrm{mg} / \mathrm{m}^{3}$, atitinkamai 4 ir 5 klasès katilams su rankiniu ir automatiniu kuro pakrovimu.

Šie duomenys rodo, kad mažiausias KD emisijas išskiria šildymo ịrenginiai, naudojantys specialiai paruoštą granuliuotą kurą bei turintys valdiklius, gebančius lanksčiai valdyti tinkamą kuro / oro tiekimą atsižvelgiant $\mathfrak{i}$ besikeičiančią apkrovą. Apie $60 \%$ tokių vandens šildymo katilų $\mathrm{KD}$ emisijos sudaro apie $20 \mathrm{mg} / \mathrm{m}^{3}$ ir yra mažiausios. Tačiau mažèjant katilo galiai KD masès

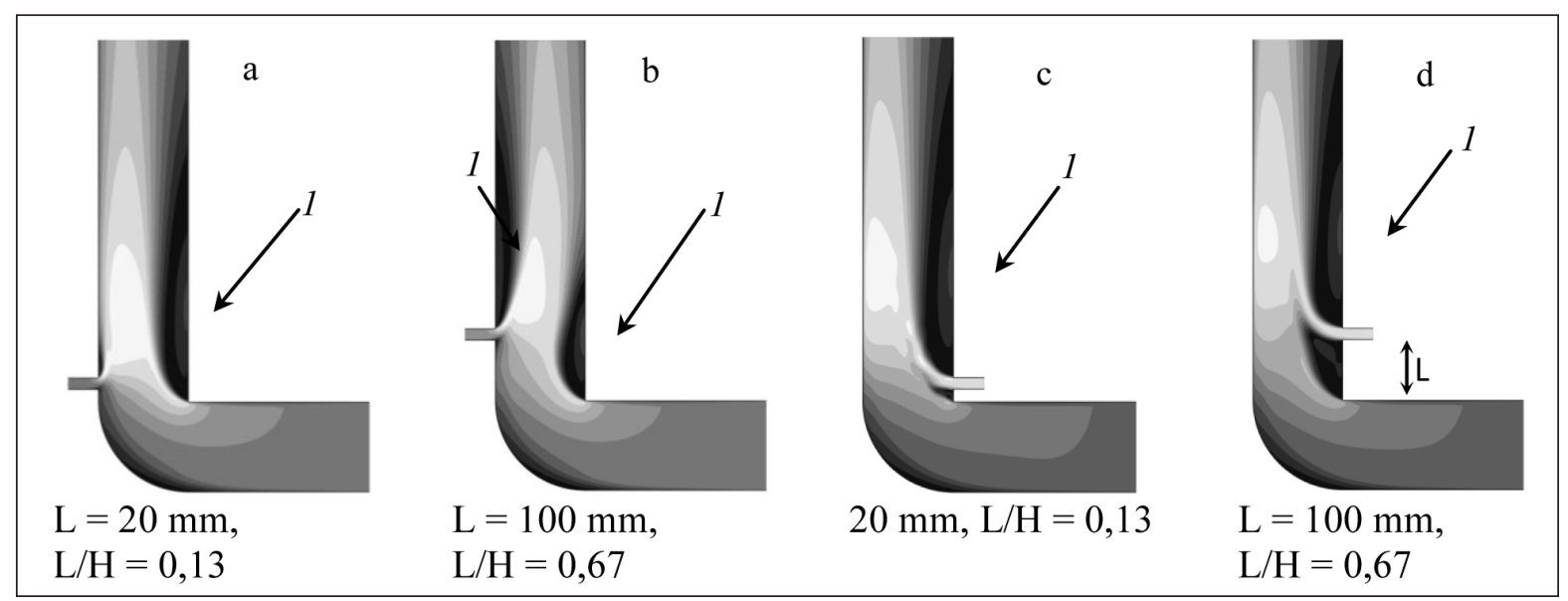

4 pav. Greičio pasiskirstymas pagal į antrinio oro j̨tekèjimo atstumo nuo posūkio kampo (L) santykị su kameros aukščiu (H): a ir b - oro tiekimas per plyši užpakalinèje sienelèje; c ir d - per plyšį priekinèje sienelèje; 1 - recirkuliacinio tekèjimo zonos 


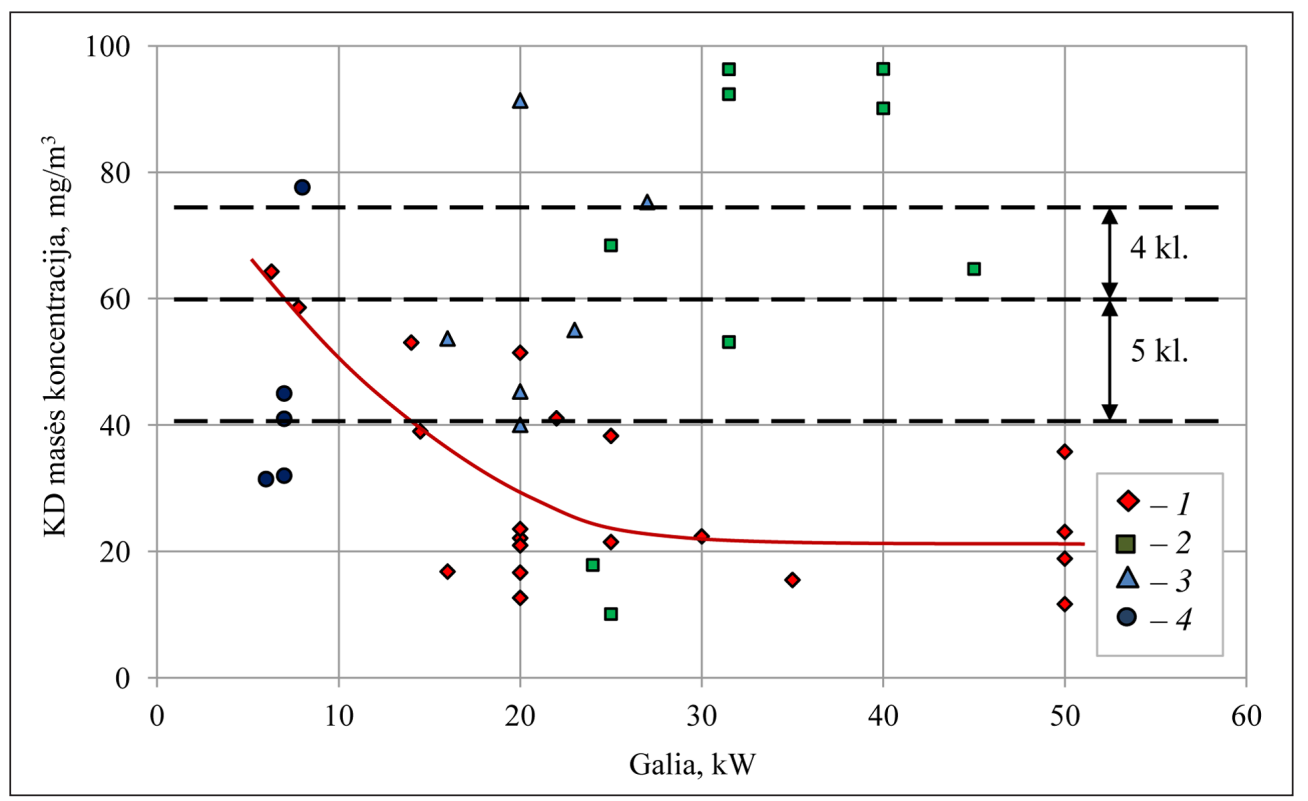

5 pav. Lietuvoje gaminamų mažos galios biokuru kūrenamų šildymo įrenginių KD masės koncentracijos dūmų dujose esant $10 \% 0_{2}: 1$ - medienos granulèmis kūrenamas katilas; 2 - malkomis kūrenamas dujų generacinis katilas; 3 - malkomis kūrenamas katilas; 4 - malkomis kūrenama krosnelè

koncentracija didèja. Šią tendenciją 5 pav. apibendrina ištisinè kreivè.

Malkomis kūrenamų vandens šildymo katilų, neatsižvelgiant i jų tipą, KD emisijos kinta nuo 20 iki $90 \mathrm{mg} / \mathrm{m}^{3}$ ir labai priklauso nuo konstrukcijos, oro degimui tiekimo ir reguliavimo ypatumų. Malkomis kūrenamoms krosnelèms, tinkamai reguliuojant pirminio ir antrinio oro degimui tiekimą, galima pasiekti KD emisijų lygi $30-45 \mathrm{mg} / \mathrm{m}^{3}$.

$\mathrm{KD}$ dūmų dujose iš $25 \mathrm{~kW}$ galios katilo, kūrenamo medienos granulemis, pasiskirstymas parodytas 6 pav., kaip dN/N (tam tikro dydžio dalelių kiekio $\mathrm{dN}$ ir suminio jų kiekio $\mathrm{N}$ santy- kio) priklausomumas nuo KD skersmens. Daleliu mėginiai buvo imami iš dalelių rinktuvo Isostac filtrų ir analizuojami spektrometru naudojant 2 matavimo celes. Matyti, kad emisijose daugiausia smulkių $0,1-0,2 \mu \mathrm{m}$ dydžio dalelių, daug mažiau $1-10 \mu \mathrm{m}$ ir nèra didesnių nei $20 \mu \mathrm{m}$.

Kūrenant kitos rūšies kietuoju kuru buvo taip pat analizuojami mèginiai, paimti iš eksploatuojamų vidutinès galios vandens šildymo katilų, aprūpintų multiciklonais ir elektrostatiniais nusodintuvais.

7 pav. pateikti $500 \mathrm{~kW}$ galios kietojo kuro katilo, aprūpinto 6 baterijų multiciklonu išmetamų i

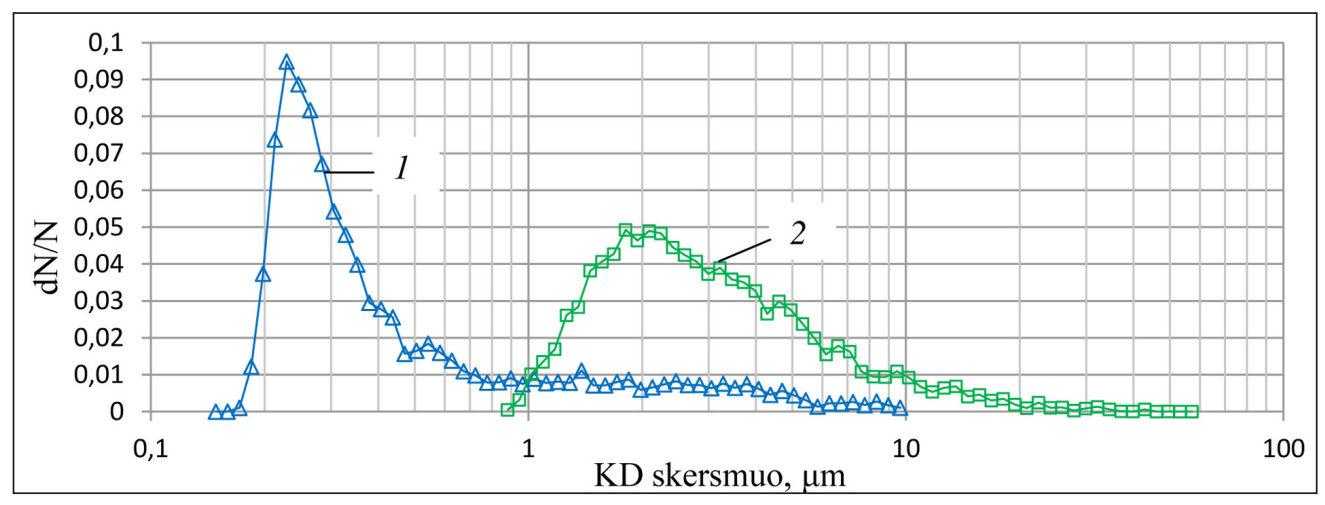

6 pav. 25 kW galios katilo, kūrenamo medienos granulemis, KD emisijų pasiskirstymas pagal dydi: 1 - celè 0,2-10 $\mu$ m; 2 - cele 2-105 $\mu \mathrm{m}$ 


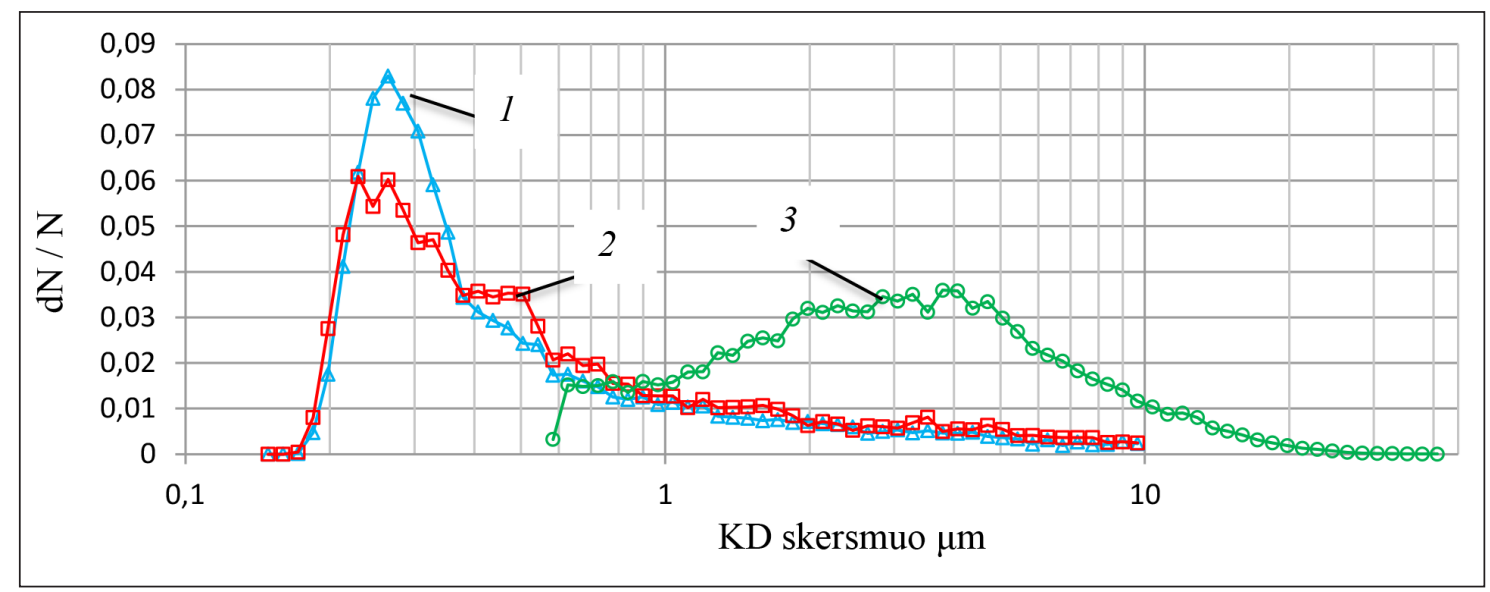

7 pav. 500 kW vandens šildymo katilo, kūrenamo medienos skiedromis, dūmų dujose ir multiciklone atskirtų KD pasiskirstymas pagal dydi: 1,2 - atitinkamai prieš multicikloną ir po jo, celè 0,1-10 $\mu \mathrm{m} ; 3$ - multiciklone, celè 1-110 $\mu \mathrm{m}$

aplinką KD kiekiui mažinti, dalelių dydžio analizės rezultatai. Katilui veikiant nominaliu režimu ir deginant medienos skiedras ant ardyno KD masès koncentracijos matuotos dūmtakyje už katilo prieš multicikloną ir $\sim 2 \mathrm{~m}$ atstumu už jo. KD masės koncentracijos matuotos automatiniu izokinetiniu KD rinktuvu, o jų pasiskirstymas pagal dydi - analogiškai anksčiau pateiktam atvejui.

Dūmų dujose didžiausias KD tankis pagal dalelių dydį nustatytas nuo 0,2 iki 0,4 $\mu \mathrm{m}$. Didžiausias tankis yra šių dydžių intervalo viduryje. Taip pat aiškiai matoma, kad dūmų dujose yra daug KD, kurių dydis nuo 0,5 iki 10-12 $\mu \mathrm{m}$. Šiame diapazone didejjant KD dydžiui, jų tankis asimptotiškai mažeja. Kadangi multiciklonas efektyviai atskiria KD, kurių dydis didesnis nei $1 \mu \mathrm{m}$, po multiciklono KD didžiausias tankis stebimas tame pačiame diapazone nuo 0,2 iki $0,5 \mu \mathrm{m}$, bet jo reikšmè gerokai mažesnè. Iš gautų rezultatų galima daryti išvadą, kad multiciklono efektyvumas smarkiai didèja didèjant dalelių dydžiams. Jau dalis net $1 \mu \mathrm{m}$ ir mažesnių dalelių gali būti atskirta multiciklonu, bet tik KD pasiekus 2-3 $\mu \mathrm{m}$ dydi atskyrimo efektyvumo didèjimo sparta ịgauna didžiausias reikšmes. Iš 6 ir 7 pav. palyginimo nematyti didelio skirtumo, ar $25 \mathrm{~kW}$ galios katilas kūrenamas medienos granulèmis, ar $500 \mathrm{~kW}$ - medienos skiedromis, išskyrus tai, kad pastaruoju atveju didèja stambesnių dalelių kiekis nuo 1 iki $10 \mu \mathrm{m}$.

Pastarasis reiškinys dar labiau išryškèja analizuojant KD, atskirtas iš dūmų dujų multiciklonais ir elektrostatiniais nusodintuvais (8 pav.). Meginiai

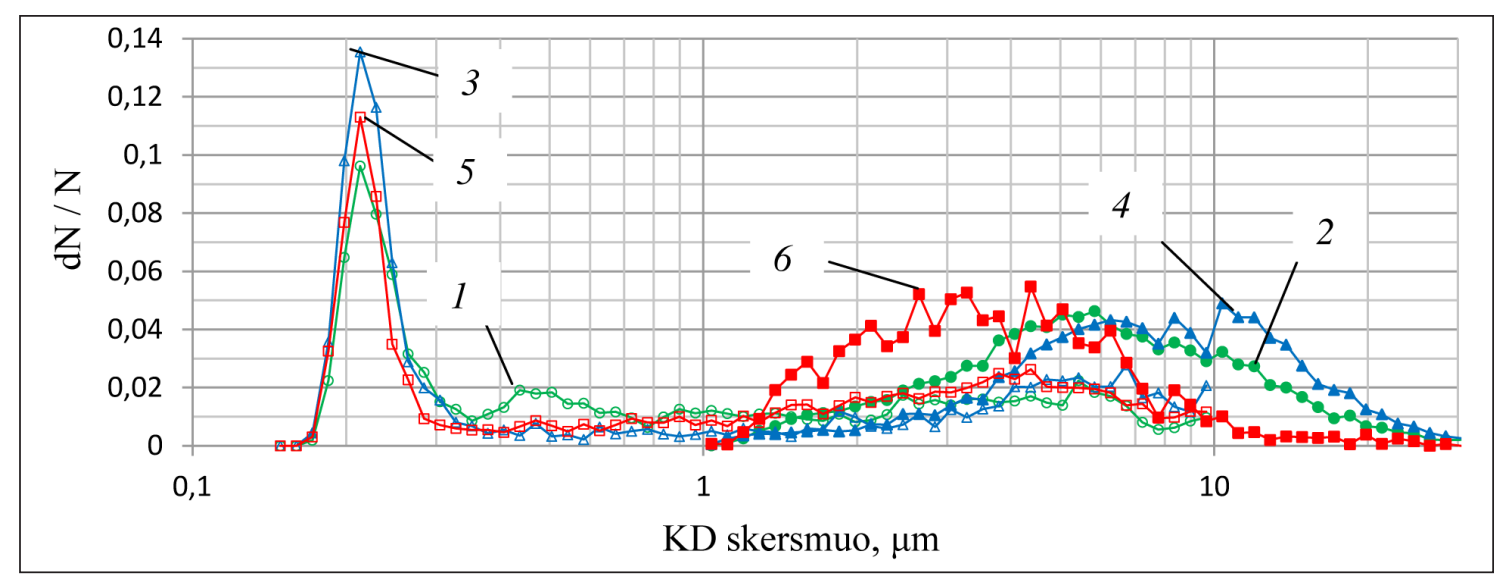

8 pav. 7 MW vandens šildymo katilo, kūrenamo medienos skiedromis, multiciklone ir elektrostatiniame nusodintuve atskirtų KD pasiskirstymas pagal dydi: 1, 2 - 1-asis multiciklonas, atitinkamai celès 0,1-10 $\mu \mathrm{m}$ ir 1-110 $\mu \mathrm{m} ; 3,4$ - 2-asis multiciklonas, atitinkamai celès $0,1-10 \mu \mathrm{m}$ ir 1-110 $\mu \mathrm{m} ; 5,6$ - elektrostatinis nusodintuvas, atitinkamai celès $0,1-10 \mu \mathrm{m}$ ir 1-110 $\mu \mathrm{m}$ 
buvo imami tiesiogiai iš dviejų 7 MW galios vandens šildymo katilų, kūrenamų medienos skiedromis, multiciklonų ir nuosekliai jiems prijungto elektrostatinio nusodintuvo kamerų. Palyginus KD dalelių pasiskirstymus, pateiktus 7 ir 8 pav., matyti, kad didejjant katilo galiai multiciklonuose atsiranda vis daugiau stambesnių $(4-10 \mu \mathrm{m}$ dydžio) dalelių. Tai susieta su intensyvesniu degimo procesu ir didesniais degimo produktų srautais. Nuosekliai irengtas elektrostatinis nusodintuvas sulaiko dar ganètinai didelị kiekị mažesnių dalelių (dydis nuo 2 iki $7 \mu \mathrm{m}$ ) ir kurių nesulaiko multiciklonas. Smulkias daleles sulaiko ne tik elektrostatinis nusodintuvas, bet ir multiciklonas.

Apibendrinant gautus rezultatus galima teigti, kad iš biomase kūrenamų îrenginių išmetamų KD koncentracija ir jų dydis kinta pagal ịrenginio tipą, jo galią ir apkrovą bei degimo režimą. Labai didelę $\mathrm{KD}$ dali pagal kiekị sudaro dalelès, kurių matmenys yra gerokai mažesni nei $1 \mu$ m, todèl îprastinès mechaninès priemonès (ciklonai, multiciklonai) dūmų dujoms nuo KD valyti nèra efektyvios. Multiciklonas pradeda atskirti KD nuo $1 \mu \mathrm{m}$ dydžio ir pasiekia atskyrimo efektyvumą $\geq 90 \%$ esant 3-4 $\mu$ m dydžio KD. Po multiciklono nuo 0,2 iki $0,5 \mu \mathrm{m}$ dydžio $\mathrm{KD}$ tankis dūmų dujose išlieka didžiausias, nes jų negalima atskirti taikant tokias dūmų dujų priemones. Siekiant užtikrinti mažas $\mathrm{KD}$ emisijas iš vidutinès ir didelès galios įrenginių, kūrenamų biokuru, privalu nuosekliai su ciklonu arba multiciklonu naudoti papildomas smulkių KD atskyrimo priemones - elektrostatinius nusodintuvus ir ịvairaus tipo medžiaginius bei keraminius filtrus.

Mažos galios $(\leq 50 \mathrm{~kW})$ vandens šildymo katilams ir patalpų šildymo prietaisams (krosnelèms, židiniams, viryklèms ir kt.) būdingi mažiau intensyvūs biokuro degimo ir oro degimui tiekimo procesai. Tai sumažina didesnių matmenų KD emisijas, bet išlieka smulkių dalelių, kurių dydis gerokai mažesnis nei $0,2-0,5 \mu \mathrm{m}$. Šios dalelès ypač kenksmingos aplinkai ir žmonių sveikatai, nes ilgai išsilaiko atmosferoje, išmetamos į nedidelius aukščius ir ị artimą taršos šaltiniui aplinką, pasižymi didele skvarba.

Elektrostatinis KD atskyrimo metodas ir tiesioginis dūmų dujų filtravimas per filtrus yra perspektyviausi metodai $\mathrm{KD}$ emisijoms iš mažos galios buitinių ir komunalinių ịrenginių mažinti dèl jų aukšto efektyvumo ir eksploatacinių savybių.

\section{IŠVADOS}

1. Biomasès sudètyje svarbiausių elementų padètis pagal jų masès koncentraciją sekose yra tokia: - medienoje - Ca, K, Si ir Mg, o Na, Zn ir Fe kiekiai beveik vienodi ar gerokai mažesni;

- javų šiauduose - Si, K, Ca ir Mg, toliau eina $\mathrm{Na}, \mathrm{Fe}, \mathrm{Pb}$ ir kiti elementai;

- žoliniuose augaluose - (panašiai kaip šiauduose) $\mathrm{Si}, \mathrm{Ca}, \mathrm{K}, \mathrm{Mg}$ ir Fe, Na, Mn bei kiti elementai.

Suminès vidutinès šių elementų koncentracijos šiauduose ir žoliniuose augaluose yra atitinkamai 6 ir 4 kartus didesnès nei medienoje. Jos koreliuoja su pelenų, susidarančių deginant biomasę, kiekiais.

2. Medienos pelenuose vyrauja $\mathrm{Ca}, \mathrm{K}$ ir $\mathrm{Mg}$, o Si ir P kiekiai mažesni nei $1,5 \%$. Šiaudų pelenuose daugiausia yra $\mathrm{K}, \mathrm{Ca}$ ir $\mathrm{Si}$, kitų elementų $0,5-2,5 \%$. Visų agromasès rūšiu pelenuose $\mathrm{K}, \mathrm{Si}$ koncentracijos didesnés nei medienos pelenuose. Šiaudų pelenai pradeda minkštèti esant $\sim 700{ }^{\circ} \mathrm{C}$ temperatūrai ir lemia ankstyvą šlakavimosi proceso pradžią. Iš agromasès grupès pagal $\mathrm{Ca}$ ir $\mathrm{K}$ bei kitų elementų kieki išsiskiria kanapès, kurių elementinè sudetis labai artima medienos pelenų sudèčiai, o SST $\geq 1000{ }^{\circ} \mathrm{C}$. Būdingosios pelenų lydumo temperatūros (DT, HT ir FT) stipriausiai koreliuoja su Si - jo kiekiui didejant, temperatūros mažèja. Ca kiekio didejjimas sukelia HT ir FT didejjimą, t. y. jo poveikis stipriau pasireiškia galutinèse lydumo stadijose. $\mathrm{Na}$ ir K poveikis - atvirkščiai - stipriau pasireiškia pradinèse lydumo stadijose, ir jų kiekio didejjimas mažina ST reikšmes. Analogiškas K poveikis taip pat stebimas ir DT reikšmèms. Apie $\mathrm{Al}$ ir kitų elementų poveikị daryti išvadų negalima, nes determinacijos koeficiento reikšmès $\leq 0,25$.

3. Mažos ir vidutinès galios vandens šildymo katilai su granuliuoto medienos kuro degikliais gali užtikrinti ne mažesnị kaip $90 \%$ naudingumo koeficientą ir mažas $\sim 20 \mathrm{mg} / \mathrm{m}^{3} \mathrm{KD}$ koncentracijas emisijose ị aplinką.

4. Iš mediena kūrenamų ịrenginių išmetamų KD koncentracija ir jų dydis kinta pagal ịrenginio tipą, jo galią ir apkrovą, degimo režimą. Labai didelę KD dalį pagal kiekị sudaro dalelès, kurių matmenys yra gerokai mažesni nei $1 \mu \mathrm{m}$. Iprastinès mechaninès priemonès (ciklonai, multiciklonai) dūmų dujoms nuo KD valyti nèra efektyvios. Siekiant užtikrinti mažas KD emisijas iš vidutinès 
ir didelès galios įrenginių, kūrenamų biokuru, privalu nuosekliai su ciklonu arba multiciklonu naudoti papildomas smulkių KD atskyrimo priemones - elektrostatinius nusodintuvus ir ivvairaus tipo medžiaginius bei keraminius filtrus.

Mažos galios ( $\leq 50 \mathrm{~kW})$ vandens šildymo katilams ir patalpų šildymo prietaisams (krosnelems, židiniams, viryklèms ir kt.) būdingi mažiau intensyvūs biokuro degimo ir oro degimui tiekimo procesai. Tai sumažina didesnių matmenų KD emisijas, bet išlieka smulkių dalelių, kurių dydis gerokai mažesnis nei $0,2-0,5 \mu \mathrm{m}$. Elektrostatinis KD atskyrimo metodas ir tiesioginis dūmų dujų filtravimas per filtrus yra perspektyviausi metodai $\mathrm{KD}$ emisijoms iš mažos galios buitinių ir komunalinių ịrenginių mažinti.

Gauta 20160630 Priimta 20161020

\section{Literatūra}

1. Lietuvos statistikos departamentas. http://osp. stat.gov.lt (žiūrèta 201605 18).

2. Obernberger I. The present state and future development of industrial biomass combustion for heat and power generation. ASME-ATI-UIT 2010 Conference on Thermal and Environmental Issues in Energy Systems, May 16-19, 2010, Sorrento, Italy.

3. Gregg P. E., Bolwig J. S., Solér S., Vejlgaard O., Gundersen L., Grohnheit S. H. Experiences with Biomass in Denmark. 2014.

4. Olsson M. Residential Biomass Combustion - Emissions of Organic Compounds to Air from Wood Pellets and Other New Alternatives. 2006.

5. Obernberger I., Christoph M. Survey on the present state of particle precipitation devices for residential biomass combustion with a nominal boiler capacity up to $50 \mathrm{~kW}$. IEA Bioenergy project Task 32 report, December 2011, Graz, Austria.

6. LST EN 303-5:2012. Šildymo katilai. 5 dalis. Rankomis ir automatiškai pakraunami kietojo kuro šildymo katilai, kurių atiduodamoji šiluminè galia iki $500 \mathrm{~kW}$. Terminijos reikalavimai, bandymai ir ženklinimas.

7. LST EN 14961-1:2010. Kietasis biokuras. Kuro specifikacijos ir klasès. 1 dalis. Bendrieji reikalavimai.
8. Fournel S., Palacios J. H., Morissette R., Villeneuve J., Godbout S., Heitz M., Savoie P. Influence of biomass properties on technical and environmental performance of a multi-fuel boiler during on-farm combustion of energy crops. Applied Energy. 2015. Vol. 141. P. 247-259.

9. Mitchell E. J. S., Lea-Langton A. R., Jones J. M., Williams A., Layden P., Johnson R. The impact of fuel properties on the emissions from the combustion of biomass and other solid fuels in a fixed bed domestic stove. Fuel Processing Technology. 2016. Vol. 142. P. 115-123.

10. Hrdlicka J., Skopec P., Dlouhy T., Hrdlicka F. Emission factors of gaseous pollutants from small scale combustion of biofuels. Fuel. 2015. Vol. 165. P. 68-74.

11. Roy M. M., Corscadden K. W. An experimental study of combustion and emissions of biomass briquettes in a domestic wood stove. Applied Energy. 2012. Vol. 99. P. 206-212.

12. Cardozo E., Erlich C., Alejo L., Fransson T. H. Combustion of agricultural residues: An experimental study for small-scale applications. Fuel. 2014. Vol. 115. P. 778-787.

13. Abreu P., Casaca C., Costa M. Ash deposition during the co-firing of bituminous coal with pine sawdust and olive stones in a laboratory furnace. Fuel. 2010. Vol. 89. P. 4040-4048.

14. Vassilev S. V., Baxter D., Andersen L. K., Vassileva C. G. An overview of the composition and application of biomass ash. Part 1. Phase-mineral and chemical composition and classification. Fuel. 2013. Vol. 105. P. 40-76.

15. Niu Y., Tan H., Hui S. Ash-related issues during biomass combustion: Alkali-inducted slagging, silicate melt-induced slagging (ash fusion), agglomeration, corrosion, ash utilization, and related countermeasures. Progress in Energy and Combustion Science. 2016. Vol. 52. P. 1-61.

16. Teixeira P., Lopes H., Gulyurtlu I., Lapa N., Abelha P. Evaluation of slagging and fouling tendency during biomass co-firing with coal in a fluidized bed. Biomass and Bioenergy. 2012. Vol. 39. P. 192-203.

17. Lindberg D., Backman R., Chartrand P., Hupa M. Towards a comprehensive thermodynamic database for ash-forming elements in biomass and waste combustion - Current situation and future 
developments. Fuel Processing Technology. 2013. Vol. 105. P. 129-141.

18. Xiao R., Chen X., Wang F., Yu G. The physicochemical properties of different biomass ashes at different ashing temperature, Renewable Energy. 2011. Vol. 36. No. 1. P. 244-249.

19. Pettersson A., Åmand L. E., Steenari B. M. Chemical fractionation for the characterisation of fly ashes from co-combustion of biofuels using different methods for alkali reduction. Fuel. 2009. Vol. 88. No. 9. P. 1758-1772.

20. Blomberg T. A thermodynamic study of the gaseous potassium chemistry in the convection sections of biomass fired boilers. Material Corrosion. 2011. Vol. 62. No. 7. P. 635-641.

21. Niu Y., Zhu Y., Tan H., Wang X., Hui S., Du W. Experimental study on the coexistent dual slagging in biomass-fired furnaces: Alkali- and silicate melt-induced slagging, Proc. Combust. Inst. 2015. Vol. 35. No. 2. P. 2405-2413.

22. Grimm A., Skoglund N., Boström D., Öhman M. Bed agglomeration characteristics in fluidized quartz bed combustion of phosphorus-rich biomass fuels. Energy and Fuels. 2011. Vol. 25. No. 3. P. 937-947.

23. Garba M. U., Ingham D. B., Ma L., Porter R. T. J., Pourkashnian M., Tan H. Z., Williams A. Prediction of potassium chloride sulfation and its effect on deposition in biomass-fired boilers. Energy and Fuels. 2012. Vol. 26. No. 11. P. 6501-6508.

24. Paulrud S. Upgraded Biofuels - Effects of Quality on Processing, Handling Characteristics, Combustion and Ash Melting. Doctoral thesis (Unit of Biomass Technology and Chemistry). Umeå: Swedish University of Agricultural Sciences, 2004. 53 p.

25. LRV $2001 \mathrm{~m}$. vasario $21 \mathrm{~d}$. patvirtinta atitikties ịvertinimo infrastruktūros (bandymų laboratorijų, sertifikacijos įstaigų) plètros programa.

26. Wang L., Hustad J. E., Skreiberg Ø., Skjevrak G., Grønli M. A critical review on additives to reduce ash related operation problems in biomass combustion applications. Energy Procedia. 2012. Vol. 20. P. 20-29.
27. Vonžodas T., Pedišius N., Valantinavičius M. Mažos galios biokuru kūrenamų vandens šildymo katilų veikimo parametrų tyrimas. Energetika. 2013. T. 59. P. 93-103.

28. Tonkonogij J., Pedišius N., Stankevičius A., Tonkonogovas A. Mažos ir vidutinès galios kietuoju kuru kūrenamų ịrenginių kietųų dalelių emisijų tyrimas. Energetika. 2015. T. 61. Nr. 3-4. P. 119130.

\section{Nerijus Pedišius, Marius Praspaliauskas, Mantas Valantinavičius, Tomas Vonžodas, Vladas Zaleckas, Egidijus Lemanas, Deimantè Čepauskienè}

\section{STUDY OF BIOFUEL PROPERTIES, EFFICIENCY AND POLLUTION PARAMETERS OF SMALL AND MEDIUM CAPACITY BOILERS FIRED WITH THIS FUEL}

\section{Summary}

Complex effectiveness and emission studies were carried out for heating boilers of low heat output, fired with wood fuel. The studies were completed in a series of stages. The first step was directed at the investigation of properties of currently used biofuel made of biomass and potentially perspective biofuel made of agromass in order to determine specific properties and how fuel should be prepared so that it could be efficiently burned in heating boilers. The second stage included numerical and experimental studies of various combustion chambers of heating boilers and air/flue gas canals in order to improve air/combustion product mixing and assuring proper combustion products' presence time in the hot zone and their temperature. During the last stage, the distribution of the particulate matter concentration in combustion products depending on their size and reduction methods of the concentration were analyzed.

Keywords: biofuel properties, ash composition and fusibility, water heating boilers, efficiency, emissions, particulate matter 